\title{
Abrogation of CC chemokine receptor 9 ameliorates collagen-induced arthritis of mice
}

\author{
Waka Yokoyama', Hitoshi Kohsaka', Kayoko Kaneko ${ }^{1}$, Matthew Walters ${ }^{2}$, Aiko Takayasu', Shin Fukuda', \\ Chie Miyabe ${ }^{1,3}$, Yoshishige Miyabe $^{1}$, Paul E Love ${ }^{4}$, Nobuhiro Nakamoto ${ }^{5}$, Takanori Kanai ${ }^{5}$, Kaori Watanabe-Imai ${ }^{1}$, \\ Trevor T Charvat ${ }^{2}$, Mark ET Penfold ${ }^{2}$, Juan Jaen ${ }^{2}$, Thomas J Schall ${ }^{2}$, Masayoshi Harigai ${ }^{1}$, Nobuyuki Miyasaka ${ }^{1}$ \\ and Toshihiro Nanki, ${ }^{1,6^{*}}$
}

\begin{abstract}
Introduction: Biological drugs are effective in patients with rheumatoid arthritis (RA), but increase severe infections. The CC chemokine receptor (CCR) 9 antagonist was effective for Crohn's disease without critical adverse effects including infections in clinical trials. The present study was carried out to explore the pathogenic roles of chemokine (C-C motif) ligand (CCL) 25 and its receptor, CCR9, in autoimmune arthritis and to study if the CCR9 antagonist could be a new treatment for RA.

Methods: CCL25 and CCR9 expression was examined with immunohistochemistry and Western blotting. Concentration of interleukin (IL)-6, matrix metalloproteinase (MMP)-3 and tumor necrosis factor (TNF)-a was measured with enzyme-linked immunosorbent assays. Effects of abrogating CCR9 on collagen-induced arthritis (CIA) was evaluated using CCR9-deficient mice or the CCR9 antagonist, CCX8037. Fluorescence labeled-CD11 b ${ }^{+}$ splenocytes from CIA mice were transferred to recipient CIA mice and those infiltrating into the synovial tissues of the recipient mice were counted.
\end{abstract}

Results: CCL25 and CCR9 proteins were found in the RA synovial tissues. CCR9 was expressed on macrophages, fibroblast-like synoviocytes (FLS) and dendritic cells in the synovial tissues. Stimulation with CCL25 increased IL-6 and MMP-3 production from RA FLS, and IL-6 and TNF-a production from peripheral blood monocytes. CIA was suppressed in CCR9-deficient mice. CCX8037 also inhibited CIA and the migration of transferred CD11 b+ splenocytes into the synovial tissues.

Conclusions: The interaction between CCL25 and CCR9 may play important roles in cell infiltration into the RA synovial tissues and inflammatory mediator production. Blocking CCL25 or CCR9 may represent a novel safe therapy for RA.

\section{Introduction}

Rheumatoid arthritis (RA) is characterized by persistent and erosive arthritis in multiple joints. The accumulation of a large number of $\mathrm{T}$ cells and macrophages [1-3], proliferation of fibroblast-like synoviocytes (FLS), production of inflammatory mediators and activation of osteoclasts are revealed in the affected joints and lead to destruction of

\footnotetext{
* Correspondence: nanki@med.teikyo-u.ac.jp

'Department of Rheumatology, Graduate School of Medical and Dental Sciences, Tokyo Medical and Dental University, 1-5-45, Yusima, Bunkyo-ku, Tokyo 110-8519, Japan

${ }^{6}$ Department of Clinical Research Medicine, Teikyo University, 2-11-1 Kaga, Itabashi-ku, Tokyo 173-8605, Japan

Full list of author information is available at the end of the article
}

the joints with pain and daily disability [4-8]. Biological drugs, such as tumor necrosis factor (TNF) blockers and interleukin (IL)-6 receptor antagonists, are effective in patients with RA [9-11]. Since the risk of severe infections is increased by biological drugs [12-14], safer therapies for RA should be developed.

As a new treatment, anti-chemokine therapy has been intensively studied for inflammatory diseases. Chemokines are a family of small secreted molecules that induce directed chemotaxis of responding cells and activation of inflammatory cells [15-17]. According to the results of a large phase II study, the CC chemokine receptor (CCR) 9 antagonist, CCX282-B was effective for Crohn's disease 
without critical adverse effects $[18,19]$. Especially, this treatment did not increase the risk of infections for 12 months. CCR9, a unique receptor for chemokine (C-C motif) ligand (CCL) 25, is expressed on lymphocytes of intestinal lamina propria and intraepithelial and dendritic cells (DCs) in the small intestine and thymocytes [20,21]. CCL25 is expressed by the follicle-associated epithelium of Peyer's patches, the crypts of Lieberkühn in the small intestine and the thymus [21,22]. Physiologically, the interaction between CCL25 and CCR9 contribute to the T cell and DC migration into the small intestine and movement of $\mathrm{T}$ cells in the thymus.

It was reported that CCR9 expression on cell surface of peripheral blood monocytes from RA patients was higher than that from healthy donors [23]. CCR9 and CCL25 were expressed on macrophages in the RA synovial tissues [23]. These data suggest that interaction of CCL25 and CCR9 may contribute to the inflammatory cell migration into the RA synovial tissues. Although blockade of CCL25 and CCR9 interaction might also be applicable to RA, the pathogenic roles of these molecules in RA have been little known.

In this study, we examined the stimulatory effects of CCL25 on FLS and monocytes and effects of the abrogation of CCR9 on a murine model of RA.

\section{Methods}

\section{Specimens}

Synovial tissue samples were obtained from eleven RA patients who fulfilled the American College of Rheumatology classification criteria for RA [24] and seven patients with osteoarthritis (OA) who underwent total knee joint replacement. Nine RA patients were positive for rheumatoid factor $(81 \%)$ and ten were positive for anti-citrullinated protein antibodies (91\%). All subjects provided written informed consent. The experimental protocols were approved by the Ethics Committee of Tokyo Medical and Dental University.

\section{Immunodetection}

Mouse anti-CCR9 (248621: R\&D Systems, Minneapolis, MN, USA), CCL25 (52513: R\&D Systems), or $\beta$-actin (AC15: Sigma-Aldrich, St Louis, MO, USA) monoclonal antibody (mAb) was used as a primary antibody for Western blotting [25]. Immunohistochemistry was conducted as described previously [25]. Frozen sections fixed with ice-cold acetone was blocked with Tris-buffered saline, $2 \%$ goat serum, $1 \%$ bovine serum albumin, $0.1 \%$ Triton X-100, and 0.05\% Tween-20. Mouse anti-CCR9, CCL25 mAb (10 $\mu \mathrm{g} /$ $\mathrm{ml}$ : R\&D Systems) or isotype control was used as a primary antibody. Alexa Fluor $^{\text {mix }}$ 546-conjugated goat anti-mouse IgG2a or IgG2b Ab $(4 \mu \mathrm{g} / \mathrm{ml}$ : Invitrogen, Carlsbad, CA, USA) was used as a secondary antibody. For double immunohistochemistry, the sections were also stained with mouse anti-CD68 (10 $\mu \mathrm{g} / \mathrm{ml}: \mathrm{KP} 1$; Dako, Glostrup, Denmark), cadherin-11 (1 $\mathrm{g} / \mathrm{ml}$ : 16A; Acris Antibodies, Hiddenhausen, Germany), or dendritic cell lysosomeassociated membrane glycoprotein (DC-LAMP) $(10 \mu \mathrm{g} / \mathrm{ml}$ : 104.G4; Immunotec Inc., Quebec, Canada) mAb. They were then incubated with $4 \mu \mathrm{g} / \mathrm{ml}$ Alexa Fluor ${ }^{\mathrm{mm}} 488$ conjugated goat anti-mouse IgG1 (Invitrogen). A nuclear stain was performed with 4', 6-diamidino-2-phenylindole. To determine the percentages of CCR9-expressed cells, the number of CCR9-positive cells in CD68-, cadherin-11-, or DC-LAMP-positive cells was counted in three randomly selected fields examined at x200 magnification under fluorescence microscope.

\section{Cell culture}

FLS was established from the RA and OA synovial tissues and used for experiments after five passages [26]. The cells did not express CD14 or human leukocyte antigen class II, suggesting that macrophages and DCs were not contained in the FLS [26]. Human peripheral blood $\mathrm{CD} 14^{+}$monocytes from healthy donors were purified by magnetic-activated cell sorting microbeads coupled with $\mathrm{mAb}$ and magnetic cell separation columns (Miltenyi Biotec, Bergisch Gladbach, Germany). The purity of CD14 ${ }^{+}$ monocytes was more than 95\%. CCR9 expression of RA FLS and purified human peripheral blood monocytes was evaluated with phycoerythrin-conjugated anti-CCR9 $\mathrm{mAb}$ (112509: R\&D Systems) or the isotype control staining using an Accuri C6 flow cytometer (Accuri Cytometers, BD Biosciences, San Jose, CA, USA). RA FLS were cultured with $10 \%$ fetal calf serum (FCS) for 48 hours with or without recombinant human CCL25 (R\&D Systems). Purified human peripheral blood monocytes were cultured with 10\% FCS for 24 hours with or without CCL25. Concentrations of IL-6, matrix metalloproteinase (MMP)-3 and TNF- $\alpha$ in the culture supernatants were measured with enzyme-linked immunosorbent assay (ELISA) kits (DuoSet: R\&D Systems).

\section{Induction and treatment of collagen-induced arthritis (CIA)}

To induce CIA, 10-week-old CCR9-deficient mice [27] and wild-type (WT) mice with a C57BL/6 J background were treated with chicken type II collagen (CII; SigmaAldrich) [28]. Eight-week-old DBA/1 J mice were treated with bovine CII (Collagen Research Center, Kiel, Germany) [29]. Disease severity was evaluated with the clinical arthritis score, incidence of arthritis, pathological score [29] and radiological score. Bone destruction was evaluated with bone erosion of the bilateral foot joints as follows: $0=$ not obvious erosion, 1 = one erosion, $2=$ two erosions, $3=$ more than three erosions, and if a bone deformity was seen in the foot joint, one point was added (to a maximum of eight points). 
DBA/1 J mice with CIA were injected subcutaneously with selective CCR9 antagonist, CCX8037 [30] or vehicle

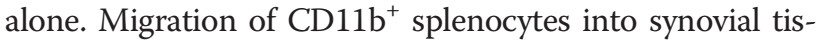
sues of CIA mice was evaluated as described previously $[31,32]$. CD11b-positive splenocytes from CIA mice were purified using magnetic-activated cell sorting microbeads coupled with mAb and magnetic cell separation columns (Miltenyi Biotec). The purified CD11b cells were labeled with CellTracker $^{\text {TM }}$ Orange 5-(and-6)-((4-chloromethyl) benzoyl) amino) tetramethylrhodamine (CMTMR: Molecular Probes, Eugene, OR, USA) according to the protocol supplied by the manufacturer. The CMTMR-labeled $1 \times 10^{7}$ cells were intravenously injected into the tail vein of CIA mice at day 9. The recipient mice were treated with CCX8037 (10 mg/kg in 1\% hydroxyprophyl methylcellulose) or vehicle 24 hours, 12 hours, and 30 minutes before the transfer, and 12 hours after the transfer. After 24 hours, ankle joints were harvested, embedded in glycol methacrylate, and sagittal 3- $\mu$ m-thick microtome sections were prepared. The numbers of CMTMR-labeled cells that migrated into the synovium between tibiotalar and tarsometatarsal joints were counted under fluorescent microscopy. The experiment protocols were approved by the Institutional Animal Care and Use Committee of Tokyo Medical and Dental University.

\section{Statistical analysis}

To compare three or more groups, including results of concentration of inflammatory mediators, area under the curve (AUC) by arthritis score, histological and radiological scores by therapeutical treatment, a one-way analysis of variance (ANOVA) test was used. To compare arthritis score, a two-way ANOVA test was used. AUC by arthritis score, histological score and radiographic score by prophylactic treatment or experiments using CCR9deficient mice, and number of migrated $\mathrm{CD}_{11 \mathrm{~b}^{+}}$splenocytes, Student's $t$ test was also applied. A $P$ value less than 0.05 was considered statistically significant.

\section{Results}

Expression of CCR9 and CCL25 in the RA synovial tissues CCR9 expression in RA and OA synovial tissues was evaluated with Western blotting. The CCR9 protein was found more in the RA synovial tissues than in the OA synovial tissues (Figure 1A). Immunohistochemical analyses of the RA synovial tissues revealed that most $\mathrm{CD}^{+} 8^{+}$ macrophages expressed CCR9 (Figure 1B-D), which is consistent with previous reports [23]. To examine the proportion of CCR9-expressed cells, the number of CCR9positive cells in $218.83 \pm 24.11 \mathrm{CD}^{+}$cells ( $\mathrm{n}=3$ ), $206.33 \pm 23.08$ cadherin $-11^{+}$cells $(\mathrm{n}=3)$ and $11.33 \pm$ $0.53 \mathrm{DC}^{-\mathrm{LAMP}^{+}}$cells $(\mathrm{n}=3)$ was counted. The percentage of CCR9-positive cells in $\mathrm{CD}^{+} 8^{+}$macrophages was $76.1 \pm 5.3 \%$. In addition, cadherin- $11^{+}$FLS and DC-LAMP ${ }^{+}$
A
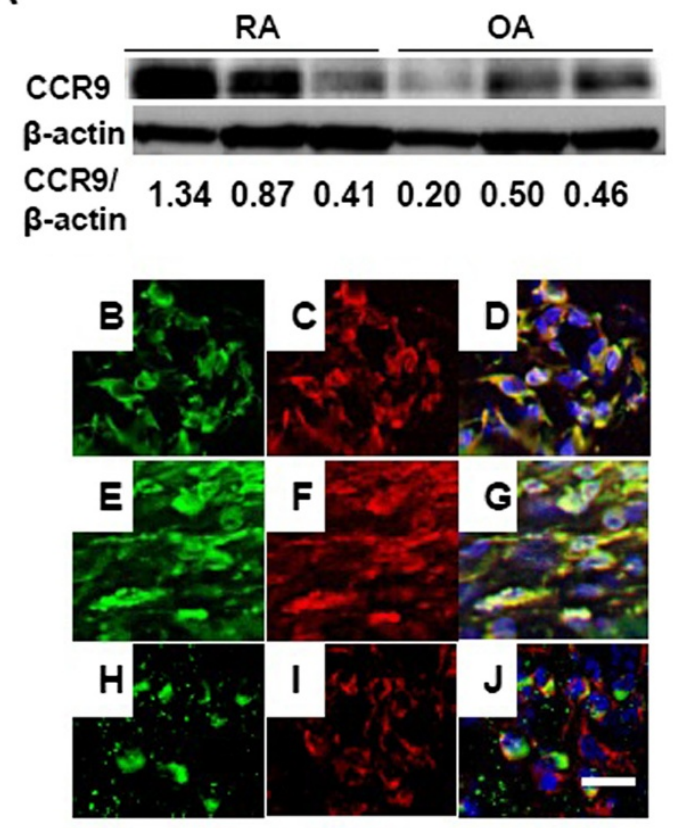

K

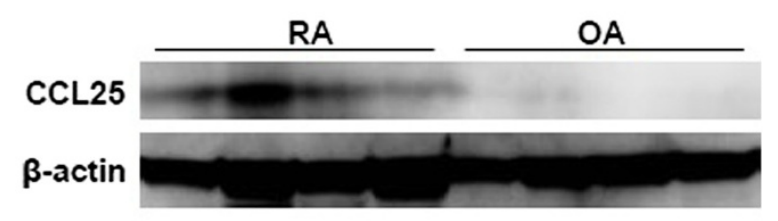

CCL25/

$\beta$-actin 2.012 .601 .620 .980 .560 .210 .170 .21
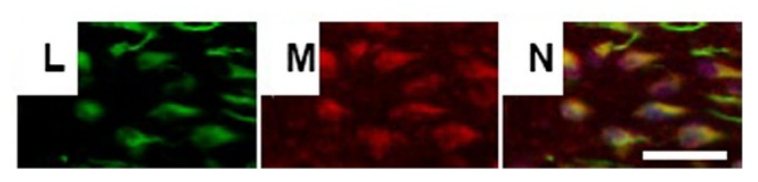

Figure 1 CCR9 and CCL25 expression in the RA synovial tissues. (A) Western blots of CCR9 protein expression in three RA and three OA synovial tissues. Ratio of CCR9/ $\beta$-actin protein level is indicated below. (B-J) Sections of RA synovial tissue were double-stained with CCR9 and CD68, cadherin-11 and DC-LAMP (B, CD68; C, CCR9; D, merged $B$ with $C$; $E$, cadherin-11; F, CCR9; G, merged E with F; H, DC-LAMP; I, CCR9; J, merged H with I). Bar, 20 Hm. (K) Western blots of CCL25 protein expression in four RA and four OA synovial tissues. Ratio of CCL25/ $\beta$-actin protein level is indicated below. (L-N) Sections of RA synovial tissue were double-stained with CCL25 and CD68 (L, CD68; M, CCL25; N, merged L with M). Bars, $20 \mu \mathrm{m}$. CCL, chemokine (C-C motif) ligand; CCR, CC chemokine receptor; DC-LAMP, dendritic cell lysosome-associated membrane glycoprotein; $\mathrm{OA}$, osteoarthritis; RA, rheumatoid arthritis.

DCs also expressed CCR9 $(67.1 \pm 8.3 \%, 11.4 \pm 15.2 \%$, respectively) (Figure 1E- J).

The CCL25 expression in RA and OA synovial tissues was analyzed with Western blotting. CCL25 was expressed more in the RA synovial tissues than in the OA synovial 
tissues (Figure $1 \mathrm{~K}$ ). Double immunohistochemistry revealed that $\mathrm{CD}_{6} 8^{+}$macrophages expressed CCL25 in the RA synovial tissues (Figure 1L-N), which is consistent with previous reports [23].

\section{Stimulatory effects of CCL25 on RA FLS and human peripheral blood monocytes}

Since FLS expressed CCR9 in the RA synovial tissues, we examined the stimulatory effects of CCL25 on the cultured RA FLS, which also expressed CCR9 (Figure 2A; mean fluorescence intensity (MFI) for CCR9: 157,963 \pm 37,811 , MFI for isotype control: 70,914 $\pm 3,163$ (mean \pm standard error of the mean (SEM)), $n=3$ ). We cultured RA FLS for 48 hours with various concentrations of CCL25. Stimulation with CCL25 increased IL-6 and MMP-3 levels in the culture supernatants in a dosedependent manner (Figure 2B). Production of TNF- $\alpha$ was not detected by unstimulated or CCL25-stimulated RA FLS. We next examined the effect of CCL25 on IL-6 and MMP-3 production by OA FLS. IL- 6 and MMP-3 were also secreted from unstimulated OA FLS, although the levels were lower than those from RA FLS (IL-6; RA: $1,393 \pm 493 \mathrm{mg} / \mathrm{dl}(\mathrm{n}=3), O A: 171 \pm 83 \mathrm{mg} / \mathrm{dl}(\mathrm{n}=2)$, $P<0.05$, MMP-3; RA: $2135 \pm 644 \mathrm{mg} / \mathrm{dl}$, OA: $296 \pm$ $50 \mathrm{mg} / \mathrm{dl}, P<0.05)$. IL-6 secretion from OA FLS was slightly increased by CCL25, although it was not statistically significant (CCL25 $5 \mathrm{ng} / \mathrm{ml}: 185 \pm 93 \mathrm{mg} / \mathrm{dl}$, $50 \mathrm{ng} /$ ml: $206 \pm 120 \mathrm{mg} / \mathrm{dl}, 500 \mathrm{ng} / \mathrm{ml}: 243 \pm 123 \mathrm{mg} / \mathrm{dl}$ ). Production of MMP-3 from OA FLS was not significantly altered by CCL25 (CCL25 $5 \mathrm{ng} / \mathrm{ml}: 324 \pm 115 \mathrm{mg} / \mathrm{dl}$, $50 \mathrm{ng} / \mathrm{ml}: 324 \pm 65 \mathrm{mg} / \mathrm{dl}, 500 \mathrm{ng} / \mathrm{ml}: 312 \pm 112 \mathrm{mg} / \mathrm{dl}$ ).

Instead of the synovial macrophages, which were not available on a large scale, we examined the effect of CCL25 on human peripheral blood monocytes. They also expressed CCR9 (Figure 3A; MFI for CCR9: 24,149 \pm 13,536, MFI for isotype control: 2,038 $\pm 1,265, \mathrm{n}=3$ ) and were cultured for 24 hours with various concentrations of CCL25. This treatment promoted IL- 6 and TNF- $\alpha$ production in a dose-dependent manner (Figure 3B).

\section{Effects of CCR9 gene deletion on murine CIA}

The above data prompted us to investigate the effect of the abrogation of CCR9 on murine CIA. We analyzed the development of CIA in CCR9-deficient mice. The clinical arthritis scores in the CCR9-deficient mice were significantly lower than those in the WT (Figure 4A). AUC by the arthritis score was calculated. The AUC tended to be smaller in CCR9-deficient mice compared to WT mice, although the difference was not statistical significant (WT: $13.40 \pm 17.75$, CCR9-deficient: $4.08 \pm 10.34$ ). Histological and radiographic examinations revealed that mononuclear cell infiltration and bone destruction were inhibited in the CCR9-deficient mice (Figure 4B and C).

\section{Effects of the CCR9 antagonist on murine CIA}

Next, we investigated the effect of the CCR9 antagonist, CCX8037, on murine CIA. To analyze its effects in a preventive protocol, CCX8037 (3 mg/kg or $10 \mathrm{mg} / \mathrm{kg}$ ) or vehicle alone was injected subcutaneously twice daily from 7 days prior to the second immunization to 14 days after the immunization. This treatment significantly inhibited clinical arthritis score in a dose-dependent manner (Figure 5A). AUC by the arthritis score was also significantly smaller by CCX8037 $(10 \mathrm{mg} / \mathrm{kg})$-treated mice compared with vehicle-treated mice (vehicle: $17.67 \pm 11.78$, CCX8037 $3 \mathrm{mg} / \mathrm{kg}: 13.67 \pm 11.79$ (not significant, vs. vehicle), CCX8037 $10 \mathrm{mg} / \mathrm{kg}: 6.79 \pm 9.22(P=0.01$, vs. vehicle)). Moreover, CCX8037 significantly inhibited mononuclear cell infiltration and bone destruction (Figure 5B and C).

To investigate the effects of CCX8037 in a therapeutic protocol, we injected CIA mice with CCX8037 $10 \mathrm{mg} / \mathrm{kg}$ or vehicle alone 5 days after the second immunization for 13 days. CCX8037 significantly inhibited arthritis, mononuclear cell infiltration and bone destruction (Figure 5D-F). AUC by the arthritis score was also significantly smaller in CCX8037-treated mice compared with vehicle-treated mice (vehicle: $30.50 \pm 16.46$, CCX8037 $10 \mathrm{mg} / \mathrm{kg}: 14.46 \pm 10.75$ $(P<0.01$, vs. vehicle $))$.
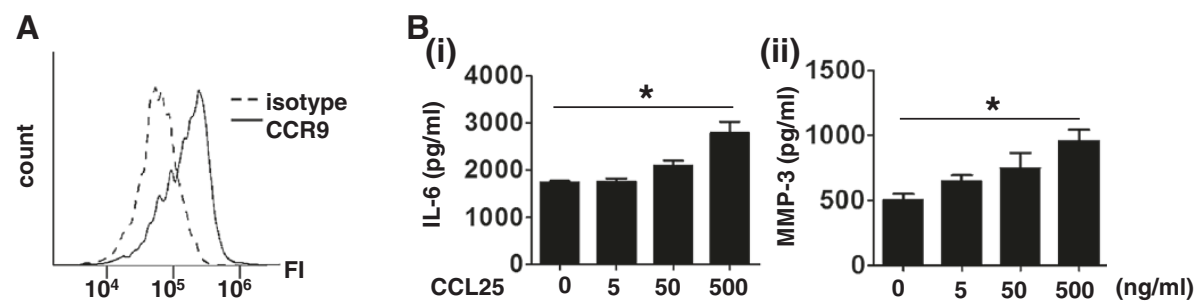

Figure 2 Effects of CCL25 on cultured RA FLS. (A) CCR9 expression on in vitro cultured RA FLS was determined by flow cytometry. Horizontal line indicates fluorescence intensity (FI). (B) RA FLS were cultured for 48 hours with various concentrations of CCL25. Concentrations of IL-6 (i) and MMP-3 (ii) in the culture supernatant were measured with ELISA. Values are the mean \pm SEM of three independent experiments. ${ }^{*} P<0.05$. CCL, chemokine (C-C motif) ligand; CCR, CC chemokine receptor; ELISA, enzyme-linked immunosorbent assay; FLS, fibroblast-like synoviocytes; IL, interleukin; MMP, metalloproteinase; RA, rheumatoid arthritis; SEM, standard error of the mean. 
A

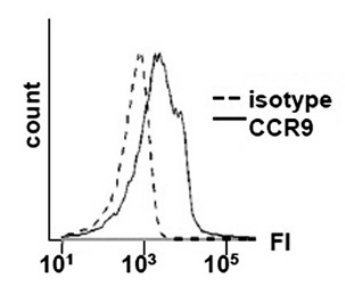

B

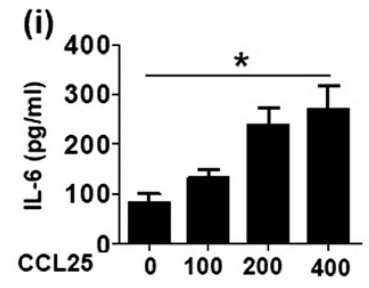

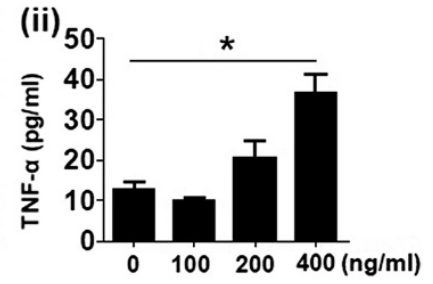

Figure 3 Effects of CCL25 on human peripheral blood monocytes. (A) CCR9 expression on peripheral blood CD14 ${ }^{+}$monocytes was analyzed with flow cytometry. (B) Monocytes were cultured for 24 hours with various concentrations of CCL25. Concentrations of IL-6 (i) and TNF-a (ii) in the culture supernatant were measured with ELISA. Values are the mean \pm SEM of three independent experiments. ${ }^{*} P<0.05$. CCL, chemokine (C-C motif) ligand; CCR, CC chemokine receptor; ELISA, enzyme-linked immunosorbent assay; IL, interleukin; SEM, standard error of the mean; TNF, tumor necrosis factor.

A

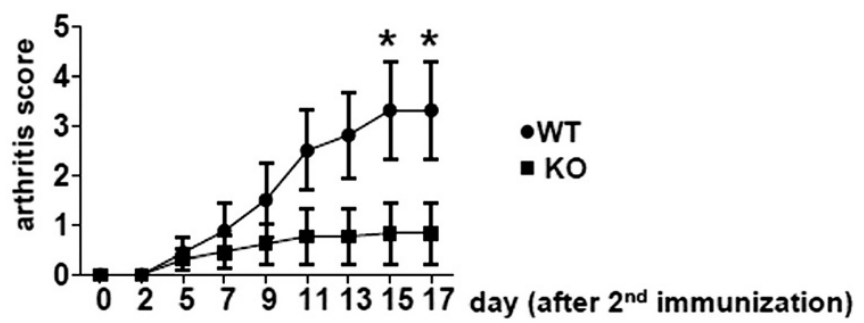

B

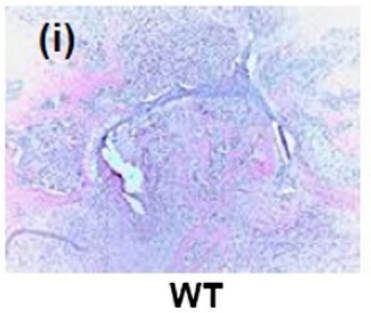

C

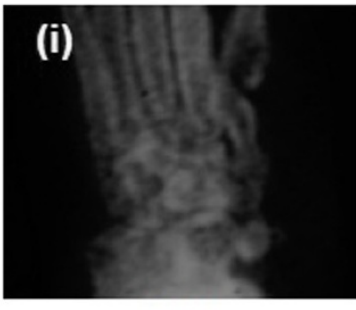

WT
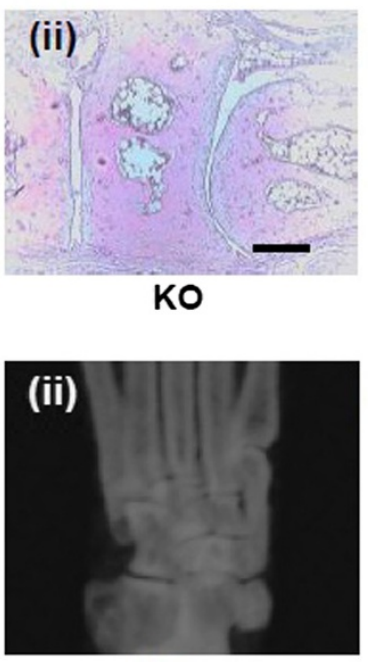

KO

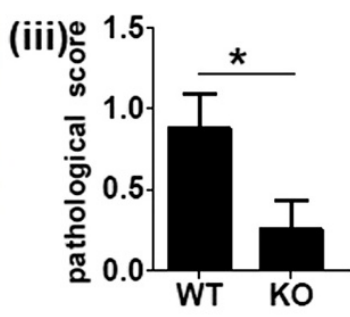

(iii)

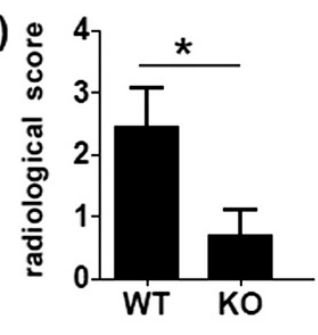

Figure 4 Suppressed CIA in CCR9-deficient mice. (A-C) CCR9-deficient mice (knockout $(K O))(n=13)$ and WT mice $(n=16)$ were immunized with chicken CII on day -21 and 0 . Day 0 means the day of the second immunization. Disease severity was recorded as the clinical arthritis score until day 18 (A). Ankle joints on day 18 from $K O(B(i))$ and WT mice (B(ii)) were stained with hematoxylin and eosin. Bar, $300 \mu m$. Inflammatory cell infiltration in the right ankle joint was scored with a pathological score (B(iii)). Representative radiographs of the ankle joints of $K O(C(i))$ and WT mice $(C(i i))$. Bone erosion in the bilateral ankle joints was scored with radiological score (C(iii)). Representative photomicrographs are shown. Values are the mean \pm SEM of each group. ${ }^{*} P<0.05$ versus WT. CCR, CC chemokine receptor; CIA, collagen-induced arthritis; CII, type II collagen; SEM, standard error of the mean; WT, wild-type. 
A

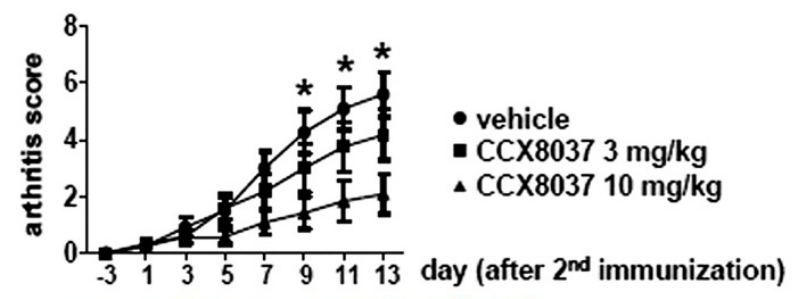

B

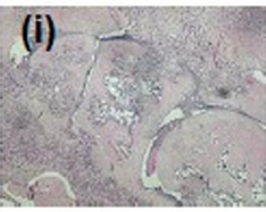

C

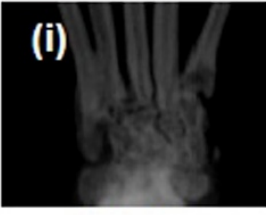

vehicle
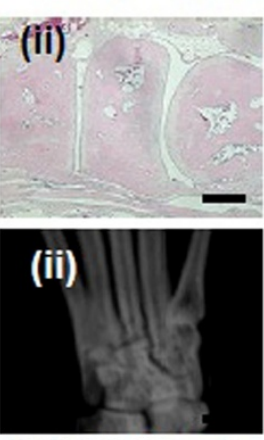

CCX8037 $10 \mathrm{mg} / \mathrm{kg}$

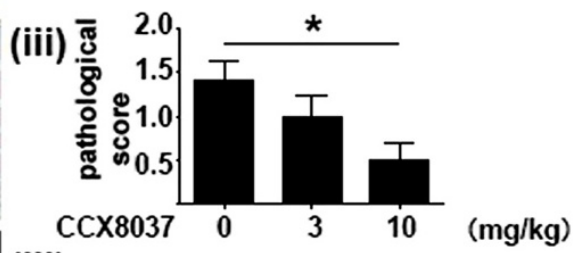

(iii)

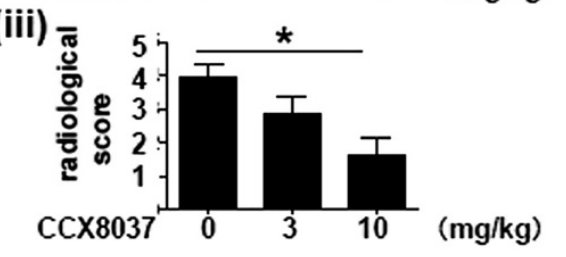

D

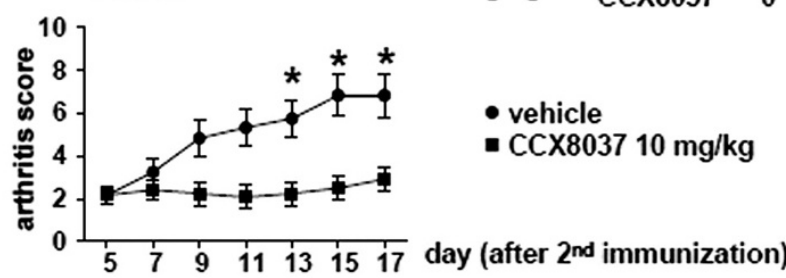

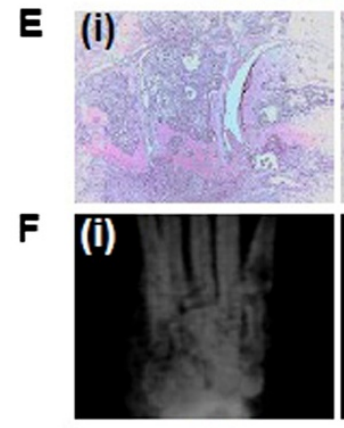

vehicle (ii)

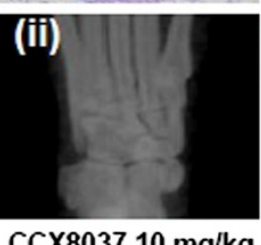

(iii)

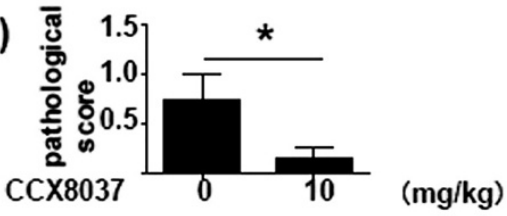

(iii)

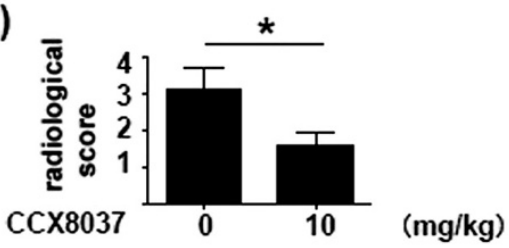

Figure 5 Effects of CCX8037 on ClA mice. (A-C) CCX8037 (3 mg/kg or $10 \mathrm{mg} / \mathrm{kg}$ ) or vehicle (all $\mathrm{n}=12$ ) was injected subcutaneously twice daily from day -7 to day 14 . Disease severity was recorded as the clinical arthritis score until day 14 (A). Representative photographs showing hematoxylin and eosin staining of the ankle joints from mice with CIA treated with vehicle (B(i)) or CCX8037 (10 mg/kg) (B(ii)). Bar, 300 m. Inflammatory cell infiltration in the right ankle joint was scored with a pathological score (B(iii)). Representative radiographs of the ankle joints of $\mathrm{ClA}$ mice treated with vehicle (C(i)) or CCX8037 $(10 \mathrm{mg} / \mathrm{kg})(C(\mathrm{ii}))$. Bone erosion in the bilateral ankle joints was scored with radiological score (C(iii)). Values are the mean \pm SEM of each group. ${ }^{*} P<0.05$, CCX8037 (10 mg kg) versus vehicle. (D-F) To investigate the therapeutic effects of CCX8037, at day 5 after the second immunization, mice were divided into two groups with equal average arthritis score. CCX8037 (10 mg/kg) or vehicle (all $n=12)$ was injected subcutaneously twice daily from day 5 to day 18. Disease severity was recorded as the clinical arthritis score (D). Representative hematoxylin and eosin staining of the ankle joints of CIA mice treated with vehicle (E(i)) or CCX8037 (10 mg/kg) (E(ii)). Bar, $300 \mu \mathrm{m}$. Pathological score (E(iii)). Representative radiographs of the ankle joints of ClA mice treated with vehicle $(F(i))$ or CCX8037 (10 mg/kg) (F(ii)). Radiological score (F(iii)). Values are the mean \pm SEM of each group. ${ }^{*} P<0.05$ versus vehicle. CCX8037, CC chemokine receptor (CCR) 9 antagonist; CIA, collagen-induced arthritis; SEM, standard error of the mean.

The CCR9 antagonist inhibited migration of CD11 $\mathrm{b}^{+}$ splenocytes

In the RA synovial tissues, most macrophages expressed CCR9, and CCL25 was abundant (Figure 1B-D and 1K). It was reported that CCL25 induced migration of monocytes/macrophages in vitro $[23,33,34]$, indicating that the interaction of CCL25 and CCR9 may have an important role in the migration of monocytes into the inflamed synovial tissues.

We then analyzed the effect of CCR9 blockade on inflammatory cell migration in vivo. We showed previously that $\mathrm{CD}_{11 \mathrm{~b}^{+}}$macrophages from CIA mice labeled and 
transferred to the recipient CIA mice were identified in the inflamed synovial tissues of the recipients [31,32]. $\mathrm{CD}_{11 \mathrm{~b}^{+}}$splenocytes express CCR9 [35]. To analyze the effect of CCX8037 on the macrophages migration, recipient mice were treated with CCX8037 or vehicle 24 hours, 12 hours, and 30 minutes before the cell transfer, and 12 hours after the transfer. Twenty-four hours after the transfer, the number of labeled cells in the synovial tissues was counted. Although, this short-term treatment did not alter the arthritis severity of the recipient mice, the treated mice had significantly reduced number of the migrated cells in the synovial tissues in contrast to the vehicletreated group (Figure 6).

\section{Discussion}

In this study, we showed that the abrogation of CCR9 ameliorated arthritis in a murine model of RA. We also found that the in vivo migration of macrophages was suppressed by the administration of CCX8037. In addition, we showed stimulatory effects of CCL25 on the production of inflammatory mediators from RA FLS and human peripheral blood monocytes in vitro. The results suggest that CCR9 could be a therapeutic target for RA.

As was reviewed earlier, chemokines are apparent therapeutic targets in RA treatment. Especially, CCR1, CCR2

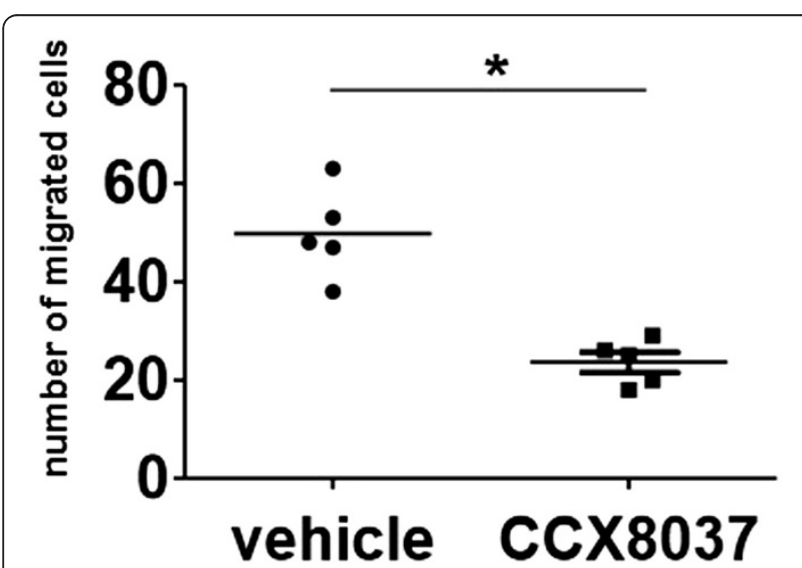

Figure 6 Effect of CCX8037 on the migration of CD11 b splenocytes into the joints. Cell Tracker Orange CMTMR-labeled CD1 $1 b^{+}$splenocytes from CIA mice $\left(1 \times 10^{7}\right)$ were adoptively transferred into each recipient CIA mouse on day 9 after the second immunization. The recipient mice were treated with CCX8037 (10 mg/ $\mathrm{kg}$ in 1\% hydroxyprophyl methylcellulose) or vehicle 24 hours, 12 hours, and 30 minutes before the transfer, and 12 hours after the transfer. Twenty-four hours after the transfer, ankle joints were harvested and examined for migrated cells under a fluorescent microscope. The total number of labeled cells in three fields of vision was counted in the synovial tissue between the tibiotalar and transmetatarsal joints $(n=5)$ at $\times 20$ magnification. Horizontal bars indicate the mean of each group. ${ }^{*} P<0.001$ versus vehicle. CCX8037, CC chemokine receptor (CCR) 9 antagonist; CIA, collagen-induced arthritis; CMTMR; 5-(and-6)-(((4chloromethyl) benzoyl) amino) tetramethylrhodamine. and CCR5 are abundantly expressed on RA synovial macrophages and the validity of CCR1, CCR2 and CCR 5 antagonist for the animal model of arthritis has been studied. CCR1 antagonist was effective in a clinical trial [36], while blockade of CCL2, CCR2 or CCR5 was not [37-39]. In the trial of CCR2 or CCR5 antagonist, no significant reduction in numbers of macrophages in the synovial tissues was observed, suggesting that CCR2 and CCR5 may not play a critical role in the migration of monocytes. In addition, since CCR2 and CCR5 are expressed on regulatory $\mathrm{T}$ cells, their blockade might inhibit regulatory $\mathrm{T}$ cells that suppressed the disease.

CCR9 was expressed on FLS, macrophages and DCs in the RA synovial tissues. This should be driven by inflammatory cytokines in the synovial tissues, since stimulation with TNF- $\alpha$ increased CCR9 expression on THP monocytic cells [23]. CCR9 was also expressed on in vitro cultured RA FLS and peripheral blood monocytes from healthy donors. CCL25 stimulated them to produce inflammatory mediators that are important in the pathogenesis of RA. CCL25 should exacerbate arthritis via these effects in addition to the inflammatory cell recruitment. We could not measure CCL25 concentration in the RA synovial tissue. However, chemokines bind surface proteoglycans [40], and they could be sequestered and presented to target cells at high concentration in the local microenvironment.

In vivo macrophage migration was suppressed by CCR9 inhibition, which might have a great impact on inhibition of CIA. It was shown that $\mathrm{CD}^{+}{ }^{+} \mathrm{T}$ cells and $\mathrm{CD} 20^{+} \mathrm{B}$ cells in the RA synovial tissues did not express CCR9 [23]. In addition, the serum concentration of anti-CII IgG1, IgG2a and IgG2b in the CCX8037-treated group was not lower than the vehicle group both in the preventive and therapeutic treatment experiments (data not shown). The effect of CCX8037 may not depend on the inhibition of T and B cells recruitment into the synovial tissues or reduction of antibody production. It was reported that deficiency of CCR9, as well as CCR1, CCR2 and CCR5, did not attenuate a murine model of serum transfer arthritis [41]. It is believed that innate immune system is important for serum transfer arthritis, while adaptive immune system is important for CIA. Macrophages and neutrophils are essential for serum transfer arthritis [41,42]. Reduction in the number of macrophages in the synovial tissues might not have enough of an impact to suppress the inflammation of arthritis in serum transfer arthritis, while that might suppress CIA. On the other hand, CCR9 was expressed on the DC-LAMP ${ }^{+}$cell in the synovial tissues, which is a mature DC [43] in the RA synovial tissues. We did not investigate the effect of the CCL25-CCR9 interaction on DCs in this study. Further studies are needed to investigate the regulation of CCR9 expression and effect of CCL25 stimulation on DCs. 
Treatment with CCR9 antagonist did not accompany critical infections as an adverse effect in a large phase II study for Crohn's disease $[18,19]$. Although the reason is not clear, it might be also the case for treating RA.

\section{Conclusions}

In this manuscript, we showed that CCL25 and CCR9 were expressed in the RA synovial tissue. Stimulation with CCL25 enhanced production of inflammatory mediators from monocytes and RA FLS. Moreover, inhibition of CCR9 reduced arthritis and inflammatory cell migration in mice. Therefore, the interaction between CCL25 and CCR9 may play important roles in cell infiltration into the RA synovial tissues and inflammatory mediator production. CCR9 antagonist may become a novel, safe and effective treatment for RA.

\section{Abbreviations \\ ANOVA: analysis of variance; AUC: area under the curve; CCL: chemokine (C-C motif) ligand; CCR: CC chemokine receptor; CIA: collagen-induced arthritis; Cll: type II collagen; CMTMR: 5-(and-6)-(((4-chloromethyl)benzoyl)amino) tetramethylrhodamine; DC: dendritic cell, DC-LAMP, dendritic cell Iysosome-associated membrane glycoprotein; ELISA: enzyme-linked immunosorbent assays; FCS: fetal calf serum; Fl: fluorescence intensity; FLS: fibroblast-like synoviocytes; IL: interleukin; KO: knockout; mAb: monoclonal antibody; MFI: mean fluorescence intensity; MMP: metalloproteinase; OA: osteoarthritis; RA: rheumatoid arthritis; SEM: standard error of the mean; TNF: tumor necrosis factor; WT: wild-type.}

\section{Competing interests}

Drs. Walters, Charvat, Penfold, Jaen and Schall own stock or stock options in ChemoCentryx, Inc. The other authors declare that they have no competing interests.

\section{Authors' contributions}

WY participated in the design of the study, carried out the experiments and statistical analysis, and drafted the manuscript. KK, AT, SF, CM, YM and KW assisted in carrying out the experiments and in manuscript preparation. MW, TC, MP, JJ and TS provided the CCR9 antagonist, participated in study design, and assisted in manuscript preparation. PL, NN and TK provided CCR9-deficient mice and assisted in manuscript preparation. HK, MH, NM and TN conceived of the study, participated in its design and coordination, and helped to draft the manuscript. All authors read and approved the final manuscript.

\section{Acknowledgements}

Supported in part by Grants-in-Aid for Scientific Research from the Ministry of Education, Culture, Sports, Science, and Technology of Japan, and Global Center of Excellence (GCOE) Program, International Research Center for Molecular Science in Tooth and Bone Diseases at Tokyo Medical and Dental University.

We thank Dr. Kazutaka Sugimoto for his critical advice and Megumi Yamaji for her excellent technical support.

\footnotetext{
Author details

'Department of Rheumatology, Graduate School of Medical and Dental Sciences, Tokyo Medical and Dental University, 1-5-45, Yusima, Bunkyo-ku, Tokyo 110-8519, Japan. ${ }^{2}$ ChemoCentryx, Inc, 850 Maude Avenue, Mountain View, CA 94043, USA. ${ }^{3}$ Department of Dermatology, Tokyo Medical University, 6-1-1 Shinjuku, Shinjuku-ku, Tokyo 160-8402, Japan. ${ }^{4}$ National Institute of Child Health and Human Development, National Institutes of Health, 9000 Rockville Pike, Bethesda, MD 20892, USA. ${ }^{5}$ Division of Gastroenterology and Hepatology, Department of Internal Medicine, Keio University School of Medicine, 35 Shinanomachi, Shinjuku-ku, Tokyo 160-8582, Japan. ${ }^{6}$ Department of Clinical Research Medicine, Teikyo University, 2-11-1 Kaga, Itabashi-ku, Tokyo 173-8605, Japan.
}

Received: 7 May 2014 Accepted: 29 August 2014

Published online: 24 September 2014

\section{References}

1. Kinne RW, Bräuer R, Stuhlmüller B, Palombo-Kinne E, Burmester GR: Macrophages in rheumatoid arthritis. Arthritis Res 2000, 2:189-202.

2. Goronzy JJ, Weyand CM: Rheumatoid arthritis. Immunol Rev 2005, 204:55-73.

3. Ritchlin C: Fibroblast biology. Effector signals released by the synovial fibroblast in arthritis. Arthritis Res 2000, 2:356-360.

4. Huber LC, Distler O, Tarner I, Gay RE, Gay S, Pap T: Synovial fibroblasts: key players in rheumatoid arthritis. Rheumatology (Oxford) 2006, 45:669-675.

5. Bartok B, Firestein GS: Fibroblast-like synoviocytes: key effector cells in rheumatoid arthritis. Immunol Rev 2010, 233:233-255.

6. Nakano K, Okada Y, Saito K, Tanaka Y: Induction of RANKL expression and osteoclast maturation by the binding of fibroblast growth factor 2 to heparan sulfate proteoglycan on rheumatoid synovial fibroblasts. Arthritis Rheum 2004, 50:2450-2458.

7. Takayanagi H, lizuka H, Juji T, Nakagawa T, Yamamoto A, Miyazaki T, Koshihara Y, Oda H, Nakamura K, Tanaka S: Involvement of receptor activator of nuclear factor kappaB ligand/osteoclast differentiation factor in osteoclastogenesis from synoviocytes in rheumatoid arthritis. Arthritis Rheum 2000, 43:259-269.

8. Gravallese EM: Bone destruction in arthritis. Ann Rheum Dis 2002, 61:ii84-ii86. 9. Smolen JS, Landewé R, Breedveld FC, Dougados M, Emery P, Gaujoux-Viala C, Gorter S, Knevel R, Nam J, Schoels M, Aletaha D, Buch M, Gossec L, Huizinga T, Bijlsma JW, Burmester G, Combe B, Cutolo M, Gabay C, Gomez-Reino J, Kouloumas M, Kvien TK, Martin-Mola E, Mclnnes I, Pavelka K, van Riel P, Scholte M, Scott DL, Sokka T, Valesini G, et al: EULAR recommendations for the management of rheumatoid arthritis with synthetic and biological disease-modifying antirheumatic drugs. Ann Rheum Dis 2010, 69:964-975.

10. Feldmann M: Development of anti-TNF therapy for rheumatoid arthritis. Nat Rev Immunol 2002, 2:364-371.

11. Nishimoto N, Yoshizaki K, Miyasaka N, Yamamoto K, Kawai S, Takeuchi T, Hashimoto J, Azuma J, Kishimoto T: Treatment of rheumatoid arthritis with humanized anti-interleukin-6 receptor antibody: a multicenter, double-blind, placebo-controlled trial. Arthritis Rheum 2004, 50:1761-1769.

12. Crawford $M$, Curtis JR: Tumor necrosis factor inhibitors and infection complications. Curr Rheumatol Rep 2008, 10:383-389.

13. Komano Y, Tanaka M, Nanki T, Koike R, Sakai R, Kameda H, Nakajima A, Saito K, Takeno M, Atsumi T, Tohma S, Ito S, Tamura N, Fujii T, Sawada T, Ida H, Hashiramoto A, Koike T, Ishigatsubo Y, Eguchi K, Tanaka Y, Takeuchi T, Miyasaka N, Harigai M, REAL Study Group: Incidence and risk factors for serious infection in patients with rheumatoid arthritis treated with tumor necrosis factor inhibitors: a report from the Registry of Japanese Rheumatoid Arthritis Patients for Longterm Safety. J Rheumatol 2011, 38:1258-1264.

14. Nishimoto N, Ito K, Takagi N: Safety and efficacy profiles of tocilizumab monotherapy in Japanese patients with rheumatoid arthritis: meta-analysis of six initial trials and five long-term extensions. Mod Rheumatol 2010, 20:222-232.

15. Szekanecz Z, Strieter RM, Kunkel SL, Koch AE: Chemokines in rheumatoid arthritis. Springer Semin Immunopathol 1998, 20:115-132.

16. Koch AE: Chemokines and their receptors in rheumatoid arthritis: future targets? Arthritis Rheum 2005, 52:710-721.

17. Vergunst CE, Tak PP: Chemokines: their role in rheumatoid arthritis. Curr Rheumatol Rep 2005, 7:382-388.

18. Eksteen B, Adams DH: GSK-1605786, a selective small-molecule antagonist of the CCR9 chemokine receptor for the treatment of Crohn's disease. IDrugs 2010, 13:472-781.

19. Keshav $S$, Vaňásek T, Niv Y, Petryka R, Howaldt S, Bafutto M, Rácz I, Hetzel D, Nielsen OH, Vermeire S, Reinisch W, Karlén P, Schreiber S, Schall TJ, Bekker P, Prospective Randomized Oral-Therapy Evaluation in Crohn's Disease Trial-1 (PROTECT-1) Study Group: A randomized controlled trial of the efficacy and safety of CCX282-B, an orally-administered blocker of chemokine receptor CCR9, for patients with Crohn's disease. PLoS One 2013, 8:e60094.

20. Zabel BA, Agace WW, Campbell JJ, Heath HM, Parent D, Roberts Al, Ebert EC, Kassam N, Qin S, Zovko M, LaRosa GJ, Yang LL, Soler D, Butcher EC, Ponath PD, Parker CM, Andrew DP: Human G protein-coupled receptor GPR-9-6/CC chemokine receptor 9 is selectively expressed on intestinal homing $T$ lymphocytes, mucosal lymphocytes, and thymocytes and is required for 
thymus-expressed chemokine-mediated chemotaxis. J Exp Med 1999, 190:1241-1256.

21. Kunkel EJ, Campbell JJ, Haraldsen G, Pan J, Boisvert J, Roberts Al, Ebert EC, Vierra MA, Goodman SB, Genovese MC, Wardlaw AJ, Greenberg HB, Parker CM, Butcher EC, Andrew DP, Agace WW: Lymphocyte CC chemokine receptor 9 and epithelial thymus-expressed chemokine (TECK) expression distinguish the small intestinal immune compartment: epithelial expression of tissue-specific chemokines as an organizing principle in regional immunity. J Exp Med 2000, 192:761-768.

22. Wurbel MA, Philippe JM, Nguyen $C$, Victorero G, Freeman T, Wooding $P$, Miazek A, Mattei MG, Malissen M, Jordan BR, Malissen B, Carrier A, Naquet P: The chemokine TECK is expressed by thymic and intestinal epithelial cells and attracts double- and single-positive thymocytes expressing the TECK receptor CCR9. Eur J Immunol 2000, 30:262-271.

23. Schmutz C, Cartwright A, Williams H, Haworth O, Williams JH, Filer A, Salmon M, Buckley CD, Middleton J: Monocytes/macrophages express chemokine receptor CCR9 in rheumatoid arthritis and CCL25 stimulates their differentiation. Arthritis Res Ther 2010, 12:R161.

24. Aletaha D, Neogi T, Silman AJ, Funovits J, Felson DT, Bingham CO, Birnbaum NS, Burmester GR, Bykerk VP, Cohen MD, Combe B, Costenbader KH, Dougados M, Emery P, Ferraccioli G, Hazes JM, Hobbs K, Huizinga TW, Kavanaugh A, Kay J, Kvien TK, Laing T, Mease P, Ménard HA, Moreland LW, Naden RL, Pincus T, Smolen JS, Stanislawska-Biernat E, Symmons D, et al: 2010 rheumatoid arthritis classification criteria: an American College of Rheumatology/European League Against Rheumatism collaborative initiative. Ann Rheum Dis 2010, 69:1580-1588.

25. Kaneko K, Miyabe Y, Takayasu A, Fukuda S, Miyabe C, Ebisawa M, Yokoyama W, Watanabe K, Imai T, Muramoto K, Terashima Y, Sugihara T, Matsushima K, Miyasaka N, Nanki T: Chemerin activates fibroblast-like synoviocytes in patients with rheumatoid arthritis. Arthritis Res Ther 2011, 13:R158.

26. Nanki T, Nagasaka K, Hayashida K, Saita Y, Miyasaka N: Chemokines regulate IL- 6 and IL-8 production by fibroblast-like synoviocytes from patients with rheumatoid arthritis. J Immunol 2001, 167:5381-5385.

27. Uehara S, Grinberg A, Farber JM, Love PE: A role for CCR9 in T lymphocyte development and migration. J Immunol 2002, 168:2811-2819.

28. Inglis JJ, Simelyte E, MCCann FE, Criado G, Williams RO: Protocol for the induction of arthritis in C57BL/6 mice. Nat Protoc 2008, 3:612-618.

29. Sato A, Watanabe K, Kaneko K, Murakami Y, Ishido M, Miyasaka N, Nanki T: The effect of synthetic retinoid, Am80, on T helper cell development and antibody production in murine collagen-induced arthritis. Mod Rheumatol 2010, 20:244-251.

30. Tubo NJ, Wurbel MA, Charvat TT, Schall TJ, Walters MJ, Campbell JJ: A systemically-administered small molecule antagonist of CCR9 acts as a tissue-selective inhibitor of lymphocyte trafficking. PLOS One 2012, 7:e50498.

31. Nanki T, Urasaki Y, Imai T, Nishimura M, Muramoto K, Kubota T, Miyasaka N: Inhibition of fractalkine ameliorates murine collagen-induced arthritis. J Immunol 2004, 173:7010-7016.

32. Miyabe Y, Miyabe C, Iwai Y, Takayasu A, Fukuda S, Yokoyama W, Nagai J, Jona M, Tokuhara Y, Ohkawa R, Albers HM, Ovaa H, Aoki J, Chun J, Yatomi Y, Ueda H, Miyasaka M, Miyasaka N, Nanki T: Necessity of lysophosphatidic acid receptor 1 for development of arthritis. Arthritis Rheum 2013, 65:2037-2047

33. Vicari AP, Figueroa DJ, Hedrick JA, Foster JS, Singh KP, Menon S, Copeland NG, Gilbert DJ, Jenkins NA, Bacon KB, Zlotnik A: TECK: a novel CC chemokine specifically expressed by thymic dendritic cells and potentially involved in T cell development. Immunity 1997, 7:291-301.

34. Chu PS, Nakamoto N, Ebinuma H, Usui S, Saeki K, Matsumoto A, Mikami Y, Sugiyama K, Tomita K, Kanai T, Saito H, Hibi T: C-C motif chemokine receptor 9 positive macrophages activate hepatic stellate cells and promote liver fibrosis in mice. Hepatology 2013, 58:337-350.

35. Nakamoto $\mathrm{N}$, Ebinuma $\mathrm{H}$, Kanai $\mathrm{T}$, Chu PS, Ono Y, Mikami $\mathrm{Y}$, Ojiro K, Lipp M, Love PE, Saito H, Hibi T: CCR9+ macrophages are required for acute liver inflammation in mouse models of hepatitis. Gastroenterology 2012, 142:366-376.

36. Tak PP, Balanescu A, Tseluyko V, Bojin S, Drescher E, Dairaghi D, Miao S, Marchesin V, Jaen J, Schall TJ, Bekker P: Chemokine receptor CCR1 antagonist CCX354-C treatment for rheumatoid arthritis: CARAT-2, a randomised, placebo controlled clinical trial. Ann Rheum Dis 2013, 72:337-344
37. Haringman JJ, Gerlag DM, Smeets TJ, Baeten D, van den Bosch F, Bresnihan B, Breedveld FC, Dinant HJ, Legay F, Gram H, Loetscher P, Schmouder R, Woodworth T, Tak PP: A randomized controlled trial with an anti-CCL2 (anti-monocyte chemotactic protein 1) monoclonal antibody in patients with rheumatoid arthritis. Arthritis Rheum 2006, 54:2387-2392.

38. Vergunst CE, Gerlag DM, Lopatinskaya L, Klareskog L, Smith MD, van den Bosch F, Dinant HJ, Lee Y, Wyant T, Jacobson EW, Baeten D, Tak PP: Modulation of CCR2 in rheumatoid arthritis: a double-blind, randomized, placebo-controlled clinical trial. Arthritis Rheum 2008, 58:1931-1939.

39. van Kuijk AW, Vergunst CE, Gerlag DM, Bresnihan B, Gomez-Reino JJ, Rouzier R, Verschueren PC, van de Leij C, Maas M, Kraan MC, Tak PP. CCR5 blockade in rheumatoid arthritis: a randomised, double-blind, placebo-controlled clinical trial. Ann Rheum Dis 2010, 69:2013-2016.

40. Tanaka Y, Adams DH, Hubscher S, Hirano H, Siebenlist U, Shaw S: T-cell adhesion induced by proteoglycan-immobilized cytokine MIP-1 beta. Nature 1993, 361:79-82.

41. Wipke BT, Allen PM: Essential role of neutrophils in the initiation and progression of a murine model of rheumatoid arthritis. J Immunol 2001, 167:1601-1608.

42. Solomon S, Rajasekaran N, Jeisy-Walder E, Snapper SB, Illges H: A crucial role for macrophages in the pathology of $\mathrm{K} / \mathrm{B} \times \mathrm{N}$ serum-induced arthritis. Eur J Immunol 2005, 35:3064-3073.

43. de Saint-Vis B, Vincent J, Vandenabeele S, Vanbervliet B, Pin JJ, Aït-Yahia S, Patel S, Mattei MG, Banchereau J, Zurawski S, Davoust J, Caux C, Lebecque S: A novel lysosome-associated membrane glycoprotein, DC-LAMP, induced upon DC maturation, is transiently expressed in MHC class II compartment. Immunity 1998, 9:325-336.

doi:10.1186/s13075-014-0445-9

Cite this article as: Yokoyama et al:: Abrogation of CC chemokine receptor 9 ameliorates collagen-induced arthritis of mice. Arthritis Research \& Therapy 2014 16:445

\section{Submit your next manuscript to BioMed Central and take full advantage of:}

- Convenient online submission

- Thorough peer review

- No space constraints or color figure charges

- Immediate publication on acceptance

- Inclusion in PubMed, CAS, Scopus and Google Scholar

- Research which is freely available for redistribution 